\title{
THEORETICAL STUDY CONCEPT OF THE GENESIS OF A CITY WITH REGARD TO SIMULATION MODELLING OF THE LONG-TERM DEVELOPMENT OF A TRANSPORTATION NETWORK. WITH ILLUSTRATIONS FROM A KLODZKO LAND CASE STUDY (SOUTH-WESTERN POLAND)
}

\author{
TEORETYCZNA KONCEPCJA BADANIA GENEZY MIASTA \\ W ASPEKCIE MODELOWANIA SYMULACYJNEGO \\ DŁUGOFALOWEGO ROZWOJU SIECI TRANSPORTOWEJ - \\ Z ILUSTRACYJNYMI PRZYKŁADAMI Z ZIEMI KŁODZKIEJ
}

\begin{abstract}
NR DOI: $10.25167 / \mathrm{sm} 2018.031 .02 \quad$ s. $25-36$
ABSTRACT: The paper presents a general outline of thoughts concerning a theoretical study concept of examining the genesis of a city. The proposed concept refers to the idea of giving a quantitative foundation for extension of the genesis of a city deeper into the past. In the proposed concept, the process of situating the city should refer to settlement actions much older than the first traces of the urbanization process and should concentrate on manifestations of movement and transportation activities. These activities may be recognizable in the archaeological record. Methodologically, the concept has a basis in the implementation of the ORION simulation modelling procedure with a special emphasis laid on long-term development of a transportation network. The method itself and the simulation procedure are described, and a possible research area is introduced.
\end{abstract}

KEY WORDS: ORION model, simulation modelling, city genesis, Klodzko Land

ABSTRAKT: Artykuł przedstawia zarys rozważań dotyczących teoretycznej koncepcji badania genezy miasta. Proponowany koncept odnosi się do zamysłu zbadania podstaw ilościowych dla znacznego wydłużenia w przeszłość genezy miasta. Proces powstawania miasta powinien odnosić się do działań osadniczych znacznie starszych niż pierwsze ślady procesu urbanizacyjnego i koncentrować się na przejawach działań związanych z przemieszczaniem i transportem. Działania te mogą być rozpoznane w źródłach archeologicznych. Metodologicznie przedstawiona koncepcja bazuje na aplikacji procedury modelowej ORION ze szczególnym naciskiem położonym na długofalowy rozwój sieci transportowej. W artykule opisana została metoda badawcza wraz z procedurą symulacyjną, a także zaproponowano potencjalny teren badań.

SŁOWA KLUCZOWE: model ORION, modelowanie symulacyjne, geneza miasta, ziemia kłodzka

\footnotetext{
* Opole University, Faculty of Economics, Chair of Economic Geography and Spatial Management, 45-058 Opole, Ozimska 46a, Poland, e-mail: jan.zipser@uni.opole.pl
} 


\section{Introduction}

The question of the genesis of a city is one of the most important in the urban planning, settlement geography, economy, history, and archaeology as well. As there are many attempts at elaborating the definition of a city, there are also distinct aspects within the scope of different research and scientific approaches regarding the development of a city (Kiełczewska-Zaleska 1969; Liszewski 2012; Piekalski 1999, 2012; Słodczyk 2012; Sołtysiak 2018; Szymańska 2009). There is quite a common agreement among the diverse disciplines, that the central European proto-cities were mostly linked to the secular or ecclesiastic centers of power and that the process of transformation from the stronghold-settlement center lingered for some time (Buko 2012; Piekalski 2012). In the case of Poland, this process started around the second half of the $10^{\text {th }}$ century and lasted approximately until the $11^{\text {th }}-12^{\text {th }}$ century (Buko 2012).

However, some aspects of the genesis of a city are still on the margin of research interest and have a geographical nature, since they correspond to the geographical space. These are the questions regarding the selection of space for urban purposes, the character of such a choice of location - whether determined by environmental factors or of the sociological/cultural nature, or finally by the aspect of the past temporal reference of the urbanization process. These issues seem to be possible to be handled by means of the quantitative approach - the simulation modelling tools developed within the research environment of urban planning and geography and tested against archaeological settlement data. Such an approach must concentrate on analyses of mutual relation between the development process of the settlement pattern, and the transportation network.

\section{Outline of the theoretical study concept}

The city formation process is a complicated one and taking into account diverse scientific and research disciplines, the research scope differs, ranging from humanoriented to space- and the city physical form-oriented (Sołtysiak 2018). And the factors that support this humanly triggered process are very diverse too (Słodczyk 2012), however those of location nature consider the geographical space (Kiełczewska-Zaleska 1969). Thus, what unifies all the possible approaches towards the examination of all the settlement processes and the urban process in particular is movement.

Movement is at the root of formation of a settlement system (Locational Analysis... 1977). According to Mumford (1961), the archetype of a city consists of graves and places of worship, which belong to the sphere of social life that can barely be transported, whilst human life is a motion between movement and settlement. Understanding expressions of human capability of moving results in a possibility to examine the settlement pattern and the rationale behind location aspects of the city genesis, since most of the city functions and the main central functions of a city are inseparably connected to movement, and consequently a transportation (communication) network 
(Kiełczewska-Zaleska 1969). An attempt to show the regularity and time sustainability in a transportation network and a settlement system spatial correspondence may help to draw conclusions about the former, dating back in time and propping against prior settlement activities, origins of decisions resulting in a city's development. The links connecting past settlement activities not only may live in the nonmaterial sphere of human heritage, crystallizing into mythologies and cults (Mumford 1961). The "linking witnesses" may be physically present for people in the past as monuments of worship or visible remnants of settlement infrastructure, such as buildings, former agricultural field systems, moats, dykes, burial places, as well as road systems, including possible route relics, that may survive centuries as an architecture pieces or archaeological record and be detectable even in the present, whether with the naked eye or in data obtained by means of Aerial Laser Scanning (ALS) (Interpreting Archaeological... 2013).

In the presented study concept, the incorporation of the archaeological record into the research consisting of simulation modelling procedures, and subsequent inferences about the city genesis may anchor the urbanization process further into the past. An analysis of the archaeological data, obtained even without the excavation process, should result in a formulation of explanation regarding the urbanization process and denoting an area of predestined settlement continuity that stays connected to the city. The archaeological data occurring with regard to the urbanization process, with no active involvement in the explanation procedures, mentioned solely to inform about prior occurrence of settlement activities is almost irrelevant to the question of the genesis of a city. The idea to incorporate archaeological residues enriches the research with the sociological characteristics, especially with regard to the transportation aspect that affects the urbanization process. The transportation network is not only a result of the physiographic situation of the terrain under examination, but for most, it is a manifestation of intentional human actions, and also presumably, holds an active role of the information medium that spreads a message from the past and for the people in the past.

The thought suggesting an active intervention in the system of agents of inanimate nature finds support in the theoretical background that supports an Actor-Network Theory (ANT). The ANT focuses mainly on the actor and explores the interconnectedness of all things. The actor can be human or nonhuman, individual or group, conscious or unconscious. According to ANT all objects and things show consciousness and thanks to this interact heterogeneously in space. The landscape is where the interactions take place, where all the objects and things are performed homogeneously (Allen 2011; Latour 2005). In the presented theoretical study concept and following the assumption of the ANT, the transportation network plays the role of a conscious and active actor creating the landscape and building an actively present continuity of the idea of the settlement structure.

The main purpose of the presented theoretical concept consists in the possibility to examine the genesis of a city with regard to a longer time span, preceding the formation of a city. Considering the lack of historical written sources for the period reflecting the genetic stage of the city formation process in the Early Medieval Period, it seems 
to be necessary to engage research methods that support not the qualitative approach, but the quantitative one, capable of producing probable scenarios of reconstruction of the urbanisation process. The theoretical assumption that underpins the proposed approach presumes that the process of placement of the city refers to settlement actions much older than the first traces of the urbanisation process. Research effort should concentrate on analyses of manifestations of the past settlement patterns and the transportation (movement) activities that maintained temporal and spatial relations in the past in the region under study.

\section{Methodological background}

Simulation modelling, even though with a relatively short history, now has a solid position in the research of many diverse disciplines worldwide (Batty 2005; Kansky 1969; Lake 2014; New advances... 2001). Regarding the simulation modelling in the area of urban planning in the Polish academic environment, one must also mention the research center of Poznan University (Geography in motion... 2018; Ratajczak 2013).

The method that seems to fit the purpose of the presented theoretical concept of the research approach regarding a city's genesis is the ORION simulation model. Some constituent elements of this modelling procedure were already introduced - however to a limited extent - in the examination and reconstruction of a probable past settlement process (Zipser J. 2011, 2014).

In 1974, T. Zipser, head of the Department of Urbanization and Spatial Planning at the Wroclaw University of Technology, began work on the construction of an extensive computer simulation system supporting decision-making and planning activities for complete settlement systems in a city and a region. The first practical applications of the newly-created ORION model (the acronym of Optative Repartition In Opportunity Network) was a tourism-related study in the Suwalki region prepared for the Polish Institute of Tourism - 1975, and the second stage of the simulation forecast of the Polish Settlement System Structure for 2000-2010, coordinated by the Institute of Geography of the Polish Academy of Sciences for State Planning Commission - 1976. In the years 1975-1990, the model was used to support decision making for a number of institutions: the Polish Institute of Trade and Services, Legnica-Glogow Copper District, former Nowosadeckie and Bielsko-Bialskie Voivodships, Poznan Agglomeration, the city of Krakow, the Krakow Metropolitan Area, the city of Bydgoszcz, and repeatedly the city of Wroclaw. The latest expert opinion using the ORION model was made in 2015 for the Municipal Urban Planning Studio in Lodz to forecast the conditions of the city's spatial development until 2025 (Ossowicz 2016; Zipser W. 2016). The above list of applications (Zipser T. 2016) shows very diverse tasks and great flexibility of the ORION simulation model.

The gravitational approach and the idea of "intervening opportunities" (Stouffer 1940, CATS 1960) within the decision-simulation ORION model are tools for determining the implementation of spatial relationships between hypothetical sources of 
these relationships. There are two model approaches: optimal decision making and "recurrent memory" mechanism, generating links between types of activities and routes of contacts. The model operates on 7-9 layers of decisions that lead to stabilized addictions within the land use system of an area. The model is based on a paradigm of 9 points that describes the relation between the civilization and space. At the interpretative level, the model, in conjunction with input factors (e.g., physiographic terrain characteristics) extended by historical data, simulates the emergence of a settlement system that remains within close internal relation with spatial dependencies. The model mechanism provides an opportunity to consider multiple variants of scenarios, providing a multi-faceted opportunity to describe the problem and identify the most likely course of development and to detect the less distortion-vulnerable outcome variants, hence assuming they are the most credible (Zipser T., Sławski 1988; Ossowicz, Sławski 1989).

For the purpose of examining the city genesis with regard to the movement, a reconstruction of the most probable transportation network should be undertaken in the region under study, covering the period from the prehistory to the Early Middle Ages. This operation should be based on the following parallel research assumptions:

An analysis of:

1. Substantial influence of cultural factors forming, to a varied degree, the functionality of the transport system. The cultural factors are perceived here as generally understood spatial relations based on a distance.

2. Based on a referential assumption of purely environmental and deterministic (geographical and environmental) origins of a transport network.

Research assumption 1. should be achieved by using a calculation mechanism of the ORION model, which is meant to strive to optimize the spatial attribution of an activity, that is an actor in the simulations process. To achieve research assumption 2., a cost surface analysis should be used (in environmentally and culturally deterministic variants).

The calculation procedure of the ORION model assumes the introduction of an original (initiating) attribution of settlement units in two variants:

V1 - In relation to the archaeological and historical sources - AZP archive record (Archeologiczne Zdjęcie Polski) for the prehistoric period and Early Middle Ages, supplemented with general historical data for the Early Medieval Period.

V2 - The hypothetical and correctional variant generated on the basis of the diffusion Shifting model (a component of the ORION procedure) based on the environmental valorisation serving the role of an "ideal" settlement system with the environmentally deterministic basis.

The following factors correcting the impact of the ORION model should be introduced.

1. The activation of a cultural factor in the ORION model by attributing to individual settlement areas (according to V1 and V2) values of cultural predisposition corresponding to distance factors reflecting the integration of local population. 
2. A variant possibility to activate a conflict procedure on the level of neighbour inconveniences between the settled zones and activities.

3. Taking into consideration a wide set of spatial contacts (set of distances) corresponding to the undertaken activities and adjusted to the individual settlement points of a corresponding prehistoric culture and early medieval settlement (or the Shifting model structure). This set concerns spatial relations representing basic activities of population groups (taking into account agricultural work, economically and socially driven travel).

4. As far as contacts are concerned, it is also necessary to consider accounts describing trips transiting through the research area. Cultural aspect - superregional relations.

5. The absorbency of individual areas should be estimated based on the assumed production capabilities of individual regions in relation to various periods/eras.

The ORION model should verify the initial distribution of activity based on the network of rectilinear links (Euclidean distance). It should be subject to modification under the pressure of spatial links between the components of a settlement structure. And so an effect of cultural aspect imaging in a decision-making process in relation to the formation of a transportation network should be achieved, manifesting itself in spatial relations of a settlement structure.

The mutual dependence in which reconstruction of the settlement and the transportation network is kept, is a condition for the ORION modelling procedure, and one of the features of this model. This characteristic feedback loop, forcing the reconstruction of a different type of the settlement structure, when maintaining the same conditions - while the contact network changes (and vice versa) - allows for testing different conditional results regarding the recreation of both, the settlement structures and the contact networks. It also secures with a high degree of certainty a good assessment of the obtained results.

Simulations leading to the optimisation of the allocation of activity determine the creation of new optimized spatial relations, which identify the location of the most optimally placed transportation routes. Based on the results achieved in the simulation procedure of the ORION model, it is possible to generate physical transport routes modified in relation to the results of the cost surface calculations. This action reflects a diagnostic application of a joint research procedure in relation to the material world and is supposed to help obtain a diagnosis of a balance between the cultural aspect and the environmentally deterministic one.

The modelling results should serve as spatial analytical indicators for a potential settlement distribution, according to the initial set of physiographic variables and directed by the accompanied set of decision making parameters. These shall represent different socio-economic stresses on the territorial use (e.g., trade ascendancy, agricultural dominance, ore mining importance), reflecting chronological description of the modelled structure.

The results achieved by means of the simulation procedure should help determine the most favourable places for the settlement in the area under study. And, as a conse- 
quence of a statistical comparison of the outcomes obtained by means of the ORION model and archive archaeological and historical data, the result ought to point to some locations, where a decision continuity in choosing to settle may have occurred. But, the engagement of the parameters that steer the modelling procedure, that are differently oriented (both, culturally- and environmentally-deterministic) and stay in many configurations, secures the obtained results against the unilateral dominance of the geographical aspects of a city's location (Kiełczewska-Zaleska 1969). On the contrary, the results give a clue about the cultural and sociological nature. Moreover, since any settlement system can be developed without a contact network (Locational Analysis... 1977), positive location correlations under the modelling-procedural condition imposing a similar transportation network, emphasize possible continuity of settlement that developed regarding exploitation of probably almost the same, sustained transportation network as used by the people who lived there before. Faced with these arguments it seems possible to deduce the origins of decisions resulting in the city development dating further back in time and relating to prior settlement activities.

The thoughts presented above concerning research of the city genesis are still only a theoretical study concept. However, it might be possible to pinpoint test research areas due to the geographical and historical conditions, where the concept might be applied. One such territory might be Klodzko Land.

\section{Possible research area}

Klodzko Land is a geographically distinct region, situated within the Sudety Mountains (south-western Poland) (Kondracki 1994). Its location, close to mountain passes, a natural gateway between the South of Europe and the European Plain, is responsible for its very turbulent history (Kladsko. Dějiny... 2012), but also offered potentially attractive settlement opportunities. Due to its location and morphologically almost perfect, box-shaped topography (mountain barriers), Klodzko Land provides a unique opportunity as a test site for interdisciplinary research regarding long-term development of a transportation network, while acting both as a frontier zone (with regard to the topography and settlement abilities) and a transit (contact) zone between people.

The first traces of human presence date back to the late Paleolithic period. The current cultural landscape reflects its crucial development in the Middle Ages, when spatially stable evidence of human activity increased in quantity and quality. Fewer in number, though stable was the settlement of the Przeworsk culture ${ }^{1}-$ the last prehistoric settlement unit in this territory before the dawn of the Slavs.

Regarding the settlement situation in the area of the present city of Klodzko during the early Middle Ages, the stronghold might have existed even in the $10^{\text {th }}$ century

\footnotetext{
1 The Przeworsk culture - an archaeological culture that developed between the middle of the $3^{\text {rd }}$ century $\mathrm{BC}$ and the $5^{\text {th }}$ century $\mathrm{AD}$ and occupied the central and southern parts of the present territory of Poland (Błażejewski 2007).
} 
(Jaworski 2012). After the second half of the $12^{\text {th }}$ century, crystallization of the urban process occurred (Kladsko ve středověkém... 2012).

What is strongly emphasized in literature, is the role of Klodzko Land in the communication between the cultural zones divided by the Sudetes and the question about the location of the transportation routes performing this role in the region (Błażejewski 2000; Bohr 2012; Bronowicki 1999; Domański 1967; Droberjar 2002; Wielowiejski 1980).

A look at a possible reconstruction of the trails in Klodzko Land, whether presented in a qualitative-descriptive manner (Bohr 2012; Domański 1967; Wielowiejski 1980) (Fig. 1) or produced by means of GIS software, reveals "naturally predictable" directions of movement in the area under study. The main mountain crossings possible to observe there, correspond even to the historical sources (Kladsko. Dějiny... 2012). This situation may be simply explained by the geographical conditions that determine or influence the most comfortable required paths of movement or those requiring least effort.

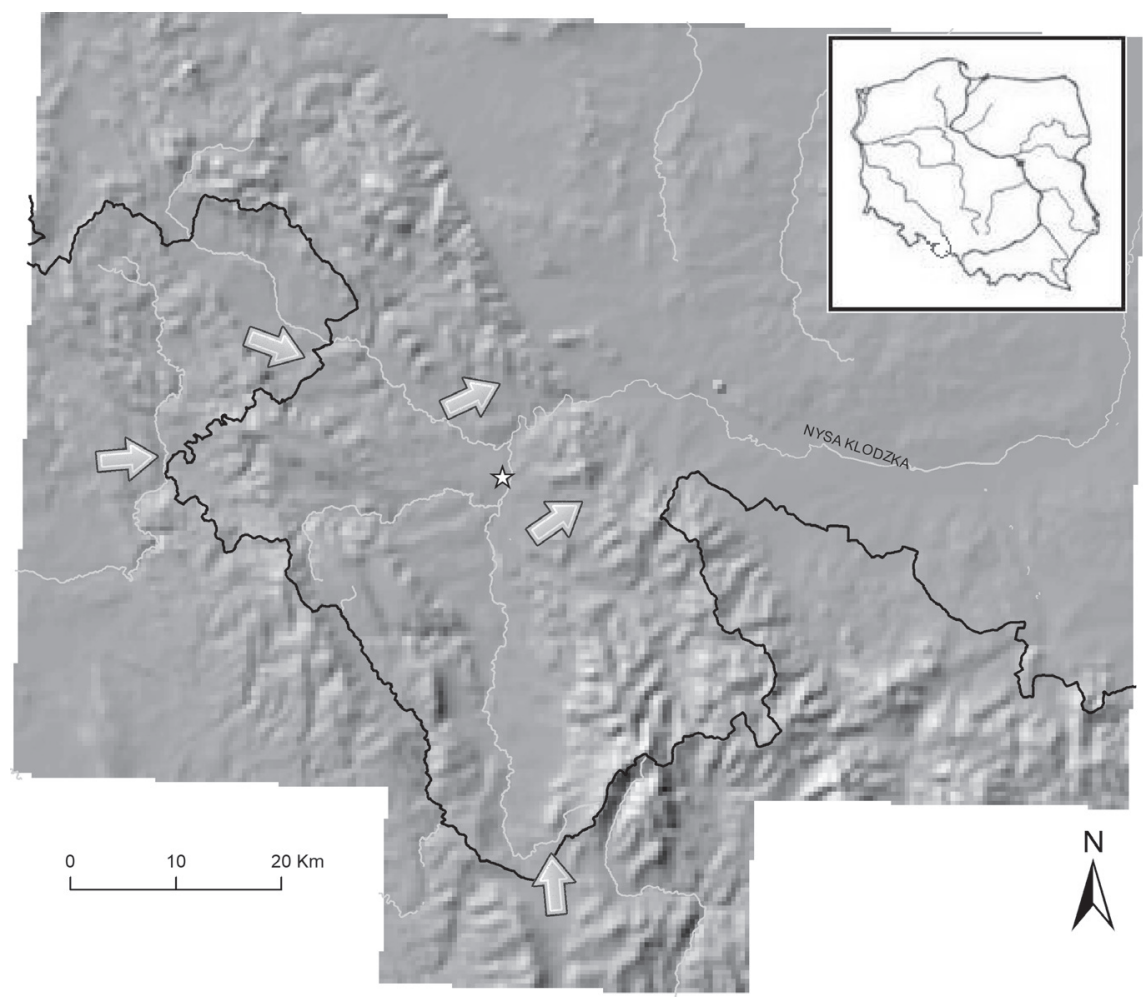

Fig. 1. Directions of the potential courses of the communication routes in Pre-Roman, Roman Iron Age and Migration Period in Klodzko Land, according to the literature. The star indicates the location of the modern city of Klodzko.

Source: own visualization based on Vmap2 (20 m resolution DEM) and (Domański 1967; Wielowiejski 1980; Bohr 201). 
However, once a probable trail reconstruction - no matter if reflecting regional (Fig. 2) or intra-regional movement (Fig. 3) - is confronted with the settlement distribution, in this case the Przeworsk culture one, some clear spatial relations occur. Apart from, again, evident environmentally determined conclusions suggesting, for instance, physical closeness to a mountain pass or the shape of a river valley that implicate the movement and foster the settlement placement, one observation is important: settlement follows the network pattern. Additionally, it is most evident in places that are important in the subsequent historical periods, in this case, in the vicinity of the city of Klodzko. One may ask: is this only a result of existing environmental conditions or is there a factor of a different, perhaps cultural or sociological, kind? Archaeological research does not absolutely negate the possibility of survival by the Przeworsk culture people in this very region and, in consequence, contacts with the incoming Slavs (Bohr 2012). If not personal relations, then maybe interference with the remnants of the material culture was the influential factor for the settlement placement and city genesis?

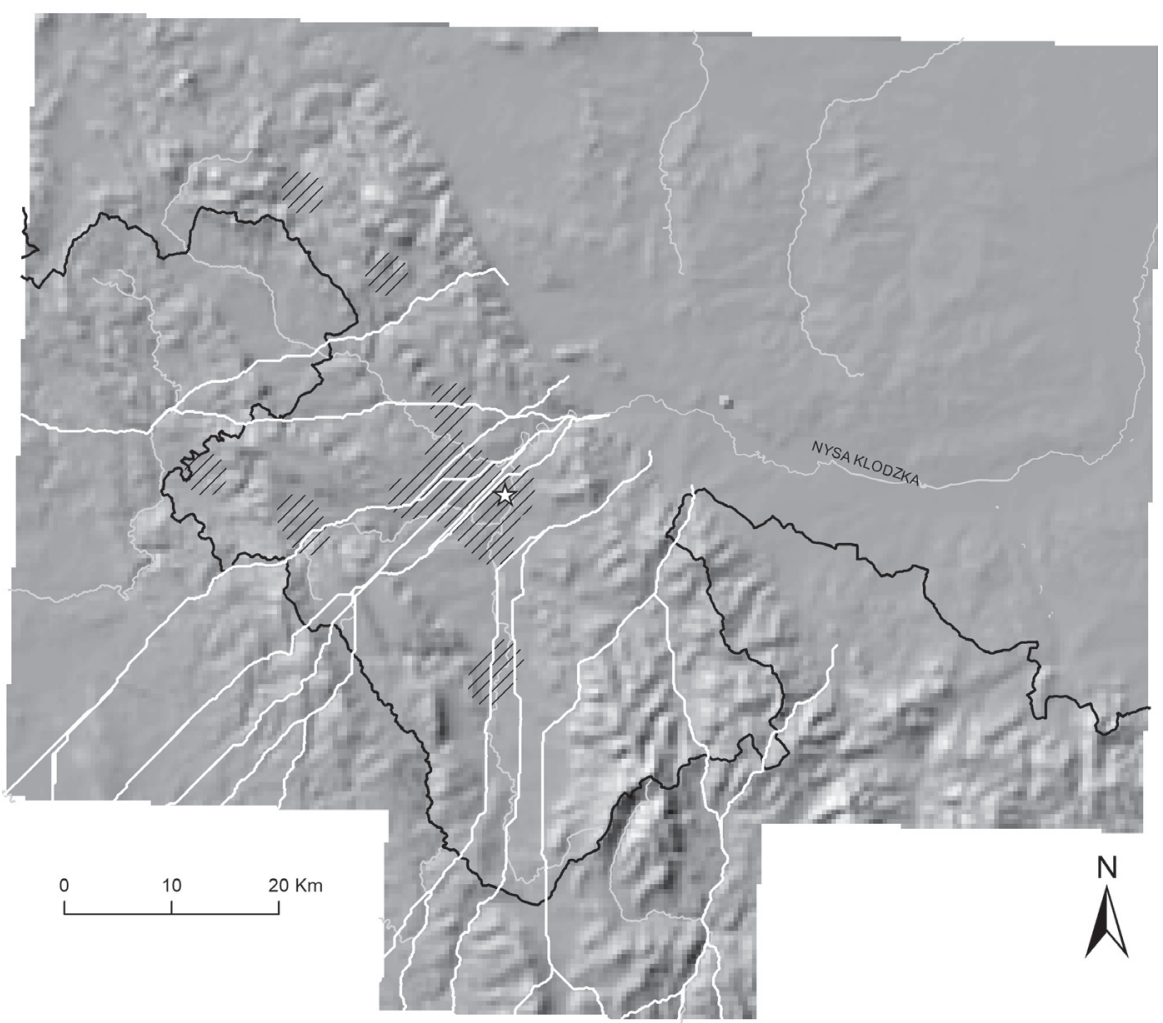

Fig. 2. An example of potential regional least-cost paths against the backdrop of the Przeworsk culture settlement (hatched areas) in Klodzko Land. The star indicates the location of modern city of Klodzko.

Source: own calculations based on Vmap2 (20 m resolution DEM) and Bohr 2012. 


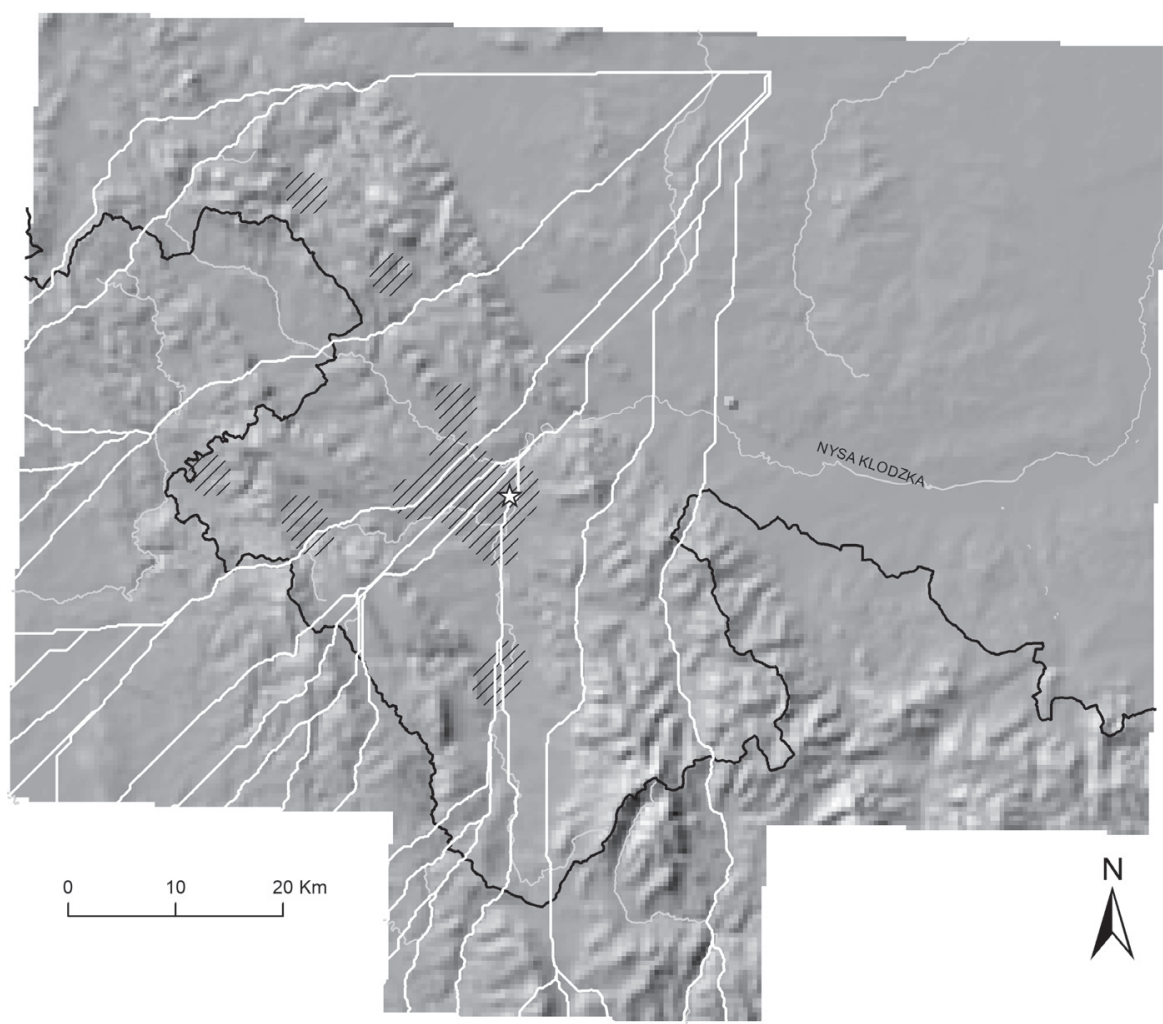

Fig. 3. An example of potential interregional least-cost paths against the backdrop of the Przeworsk culture settlement (hatched areas) in Kłodzko Land. The star indicates the location of modern city of Klodzko.

Source: own calculations based on Vmap2 (20 m resolution DEM) and Bohr 2012.

Once possible reasons for settlement choices in the past are introduced, more interesting aspects of the problem occur. For instance, what was the balance between these environmental and cultural factors, since for sure not just one type of factors was in the play? Or what was the sequence of mutual influences of the placement factors? Finally, to conclude the presented here incomplete list of the circumstances from which people of the past could choose to decide on the settlement act, how deep into the past can we search for settlement relations of city origins, specifically in the central European environment?

Unless, the settlement decision is always just a human, non conditional impulse?

It seems like the best research procedure that may be introduced to treat many of the questions presented - perhaps with the exception of the very last one - is simulation modelling and ORION model in particular. It is due to the model's ability to create multilayered conditional scenarios of probable settlement processes, which - in case of city genesis - are always complex and require a multidimensional approach. 


\section{Conclusions}

Keeping in mind the obvious limitations of the proposed research concept regarding the examination of the city genesis, such as possible scarcity of the archaeological record or the necessity to implement theoretical variables instead of the measured ones, etc., the research conducted according to the presented concept may influence the development of not only those research areas that deal with the past as historical geography and archeology, but also those areas rooted in the present and future, such as regional economy and spatial planning. And finally, the results obtained following the proposed research concept may increase the local community's historical cognizance and support the local heritage strategy as well as regional development policies.

\section{References}

Allen C.D., 2011, “On Actor-Network Theory and Landscape”, Area, 43.3, p. 274-280.

Banaszek M., Dziecielski M., Nijkamp P., Ratajczak W., 2013, “Geography in Motion: Hexagonal Spatial Systems in Fuzzy Gravitation”, Environment and Planning A: Economy and Space, Issue 50(6), https:// journals.sagepub.com/doi/abs/10.1177/0308518X18790249 [access: 30.12.2018].

Batty M., 2005, “Network geography: Relations, interactions, scaling and spatial processes in GIS”, In: P.F. Fisher, D. Unwin (eds), Re-presenting GIS, Wiley, Chichester, p. 149-169.

Błażejewski A., 2000, "Sudety polskie w okresie przedrzymskim i wpływów rzymskich - zarys problematyki”, In: W. Boguszewicz, A. Boguszewicz, D. Wiśniewska, Człowiek i środowisko w Sudetach, Regionalny Ośrodek Studiów i Ochrony Środowiska Kulturowego, Wrocław, p. 121-134.

Błażejewski A., 2007, Starożytni Stowianie, Zakład Narodowy im. Ossolińskich, Wrocław.

Bohr M. 2012, "Kotlina Kłodzka w okresie wpływów rzymskich i wczesnym okresie wędrówek ludów”, Silesia Antiqua, vol. 48, p. 39-69.

Bronowicki J., 1999, “Dotychczasowe rozpoznanie problematyki epoki kamienia”, In: P. Valde-Nowak (ed.), Początki osadnictwa $w$ Sudetach, Instytut Archeologii i Etnologii Polskiej Akademii Nauk, Kraków, p. 19-25.

Buko A., 2012, “Świt urbanizacji europejskiej”, In: S. Tabaczyński, A. Marciniak, D. Cyngot, A. Zalewska (eds), Przeszłość społeczna. Próba konceptualizacji, Wydawnictwo Poznańskie, Poznań, p. 248-265.

CATS, 1960, Final Report, vol. II, Chicago.

Cetwiński M., Musil F., Šandera M., 2012, "Kladsko ve středověkém českém státě (konec 11 století - 1459)", In: O. Felcman, R. Gładkiewicz (eds), Kladsko. Dějiny regionu, Filozofická fakulta UHK; Polsko-Czeskie Towarzystwo Naukowe; Historický ústav AV ČR; Powiat Kłodzki, Hradec Králové-Wrocław-PrahaKłodzko, p. 47-113.

Domański G., 1967, „Szlaki handlowe w okresie późnolateńskim i wpływów rzymskich w Sudetach Polskich”, Acta Archaeologica Carpathica, vol. 9, p. 85-89.

Droberjar E., 2002, Encyklopedie řimské a germánské archeologie v Čechách a na Moravě, Libri, Praha.

Haggett P., Cliff A.D., Frey A., 1977, Locational Analysis in Human Geography, vol. 2, Wiley, New York.

Interpreting Archaeological Topography: 3D Data, Visualisation and Observation, 2013, Opitz R., Cowley D. (eds), Oxbow Books, Oxford.

Jaworski K., 2012, “Kladsko v pravěku a raném středověku (do konce 11 století)”, In: O. Felcman, R. Gładkiewicz (eds), Kladsko. Dějiny regionu, Filozofická fakulta UHK; Polsko-Czeskie Towarzystwo Naukowe; Historický ústav AV ČR; Powiat Kłodzki, Hradec Králové-Wrocław-Praha-Kłodzko, p. 15-46.

Kansky K., 1969, Structure of Transportation Networks: Relationships Between Network Geometry and Regional Characteristics, University of Chicago Press, Chicago.

Kiełczewska-Zaleska M., 1969, Geografia osadnictwa, PWN, Warszawa. 
Kladsko. Dějiny regionu, 2012, O. Felcman, R. Gładkiewicz (eds), Filozofická fakulta UHK; Polsko-Czeskie Towarzystwo Naukowe; Historický ústav AV ČR; Powiat Kłodzki, Hradec Králové-Wrocław-PrahaKłodzko.

Kondracki J., 1994, Geografia Polski. Mezoregiony fizyczno-geograficzne, Wydawnictwo Naukowe PWN, Warszawa.

Lake M.W., 2014, “Trends in Archaeological Simulation”, Journal of Archaeological Method and Theory, No 21(2), p. 258-287.

Latour B., 2005, Reassembling the Social: An Introduction to Actor-Network-Theory, Oxford University Press, Oxford-New York.

Liszewski S., 2012, Wstęp, In: S. Liszewski (ed), Geografia urbanistyczna, Wydawnictwo Naukowe PWN, Warszawa, p. 9-13.

Mumford L. 1961, The City in History, Penguin Books, Harmondsworth-Ringwood-Auckland.

Ossowicz T., 2016, „Prognozowanie opuszczania miejsc dotychczas zajmowanych przez mieszkańców i przedsiębiorców”, Architectus, No. 3(47), p. 33-41.

Ossowicz T., Sławski J., 1989, “The Allocation Model ORION: Its Development and Applications”, Papers of Regional Science Association, vol. 66, p. 31-46.

Piekalski J., 1999, Od Kolonii do Krakowa. Przemiana topografii wczesnych miast, Sudety, Wrocław.

Piekalski J., 2012, „Wczesne miasta Europy Środkowej”, In: S. Tabaczyński, A. Marciniak, D. Cyngot, A. Zalewska (eds), Przeszłość społeczna. Próba konceptualizacji, Wydawnictwo Poznańskie, Poznań, p. $266-272$.

Ratajczak W., 2013, Obiekty, struktury i procesy przestrzenne. Analiza fraktalna, Bogucki Wydawnictwo Naukowe, Poznań.

Reggiani A., Nijkamp P., Sabella E., 2001, “New Advances in Spatial Network Modelling: Towards Evolutionary Algorithms”, European Journal of Operational Research, vol. 128(2), p. 385-401.

Słodczyk J. 2012, Historia planowania i budowy miast, Wydawnictwo Uniwersytetu Opolskiego, Opole.

Sołtysiak M., 2018, Narodziny miast na północnym zachodzie ziem polskich w średniowieczu. Interdyscyplinarne badania nad rozwojem urbanistycznym i ekonomicznym średniowiecznych ośrodków z północnych i zachodnich ziem polskich w świetle źródeł archeologicznych (unpublished).

Stouffer, A.S., 1940, "Intervenning Opportunities: A Theory Relating Mobility and Distance", American Sociological Review, vol. 5(6), p. 845-867.

Szymańska D., 2009, Geografia osadnictwa, Wydawnictwo Naukowe PWN, Warszawa.

Wielowiejski J., 1980, Główny szlak bursztynowy w czasach cesarstwa rzymskiego, Zakład Narodowy im. Ossolińskich, Wrocław-Warszawa-Kraków-Gdańsk.

Zipser J., 2011, Dyfuzja osadnictwa kultury lateńskiej (celtyckiej) na Śląsku Górnym i Opawskim w ujęciu czasowo-przestrzennym (unpublished PhD thesis), Wrocław.

Zipser J., 2014, „Koncepcja teoretyczna modelu dyfuzji osadnictwa dla potrzeb analizy procesów osadniczych górnośląskiej grupy kultury lateńskiej”, Śląskie Sprawozdania Archeologiczne, vol. 56, p. 61-78.

Zipser T., 2016, „Przewidywanie stanów, modelowanie procesów i budowanie decyzji”, Architectus, No. 3(47), p. 3-13.

Zipser T., Sławski J., 1988, Modele Procesów Urbanizacji. Teoria i jej wykorzystanie w praktyce planowania, Państwowe Wydawnictwo Ekonomiczne, Wrocław.

Zipser W., 2016, „Prognozowanie działań rewitalizacyjnych w miastach”, Architectus, No. 3(47), p. 43-55.

https://www.academia.edu/35066403/Narodziny_miast_na_p\%C3\%B3\%C5\%82nocnym_zachodzie_ziem_ polskich_w_\%C5\%9Bredniowieczu._Interdyscyplinarne_badania_nad_rozwojem_urbanistycznym_i_eko nomicznym_\%C5\%9Bredniowiecznych_o\%C5\%9Brodk\%C3\%B3w_z_p\%C3\%B3\%C5\%82nocnych_i_zachodnich_ziem_polskich_w_\%C5\%9Bwietle_\%C5\%BAr\%C3\%B3de\%C5\%82_archeologicznych 